\title{
Agrostis meyenii Trin. (Poaceae, Agrostidinae): first records from Peru, including taxonomic notes and an identification key
}

\author{
Steven P. Sylvester ${ }^{1}$, Mitsy D.P.V. Sylvester ${ }^{1,2}$ \\ 1 Nanjing Forestry University, College of Biology and the Environment, Long Pan Road No. 159, Nanjing, Jiangsu, 210037, China. 2 Universidad \\ Nacional de San Antonio Abad del Cusco, Avenida de la Cultura 733, Cusco, Perú. \\ Corresponding author: Steven P. Sylvester, steven_sylvester@hotmail.com.
}

\begin{abstract}
The grass Agrostis meyenii Trin. (Poaceae, Agrostidinae) is newly recorded from Peru and is found in high-Andean puna grasslands of the departments of Ancash, Ayacucho, and Huánuco, marking the northernmost known limit of this species. A revised species description, images, taxonomic notes, and a key are also presented to differentiate $A$. meyenii from similar species in Peru with congested, spike-like panicles and absent or reduced (measuring less than $1 / 2$ the length of the lemma) paleas (i.e., A. breviculmis Hitchc., A. foliata Hook.f., and A. tolucensis Kunth).
\end{abstract}

\section{Keywords}

Andes, Gramineae, grass, identification key, puna grassland, taxonomy

\section{Introduction}

The grass genus Agrostis L. belongs to tribe Poeae R.Br., subtribe Agrostidinae Fr. (Soreng et al. 2017) and is morphologically defined by taxa with membranous ligules, paniculate inflorescences composed of one-flowered, laterally compressed spikelets, glumes usually amply surpassing the florets, florets lacking a rachilla extension emerging from under the palea, and calluses glabrous or short pilose, among other characteristics. The taxonomy of Agrostis is continuing to undergo upheaval as more molecular and morphological data becomes available and, while traditionally considered to contain many genera (e.g. Podagrostis (Griseb.) Scribn. \& Merr., Lachnagrostis Trin.) (Clayton and Renvoize 1986; Watson and Dallwitz 1992) many of these have since been considered distinct (e.g. Soreng et al. 2017; Sylvester et al. 2020a).
Within Peru, besides species protologues, the only taxonomic treatment available on Agrostis is the country-wide treatment of the grasses of Peru by Tovar (1993), who cited 15 species. Oscar Tovar Serpa also helped with the checklist for Peru, published in the same year (Davidse et al. 1993), that confusingly cites 18 species, including many, but not all, of those from Tovar's (1993) treatment, with some of these being placed in synonymy and other species of Bromidium Nees \& Meyen being considered under Agrostis (e.g. Bromidium anomalum (Trin.) Döll, B. tandilense (Kuntze) Rúgolo), as well as A. magellanica Lam., and $A$. nigritella Pilg. (= A. foliata Hook.f.). Davidse et al.'s (1993) checklist is also replicated in the W3TROPICOS-Peru Checklist (2020), although many of the names have since been placed in synonymy 
or transferred to other genera (Soreng et al. 2003, 2003 and onwards; Sylvester et al. 2020a). Despite ca 27 years since the publication of the aforementioned checklist and taxonomic treatment (Davidse et al. 1993; Tovar 1993), no new records or discoveries of new species of Agrostis have been made for Peru until now. During herbarium research at the United States National Herbarium (US), specimens of Agrostis meyenii Trin., a species recorded further south in Bolivia, Argentina, and Chile (Renvoize 1998; Rúgolo de Agrasar 2012; Jørgensen et al. 2014), were encountered and mark the northernmost distribution of this species recorded to date. With the addition of $A$. meyenii, and including taxa previously circumscribed in Bromidium based on indications from recent phylogenetic research (Tkach et al. 2020), it is currently estimated that 13 species of Agrostis are present in Peru (A. breviculmis Hitchc.; A. foliata Hook.f.; A. gigantea Roth; A. hyemalis (Walter) Britton, Sterns \& Poggenb.; A. imberbis Phil.; A. koelerioides É.Desv.; A. mertensii Trin.; A. meyenii; A. perennans (Walter) Tuck.; A. stolonifera L.; A. subrepens (Hitchc.) Hitchc.; A. tandilensis (Kuntze) Parodi; A. tolucensis Kunth) (Davidse et al. 1993; Tovar 1993; Soreng et al. 2003 and onwards; Plants of the World Online 2020; Sylvester et al. 2020a). However, a taxonomic reappraisal of Peruvian Agrostis is urgently needed, with our research contributing to this.

\section{Methods}

Accepted species follow Soreng et al. (2003 and onwards). Herbarium acronyms follow Thiers (2020). The US herbarium was visited during the study. The identity of the A. meyenii voucher specimens for Peru was verified by morphological comparison with type specimens at the US herbarium and on JSTOR Global Plants (https://plants.jstor.org/) and other specimens collected from Argentina and Chile, while ascertaining that morphological characteristics coincide with those stated in type protologues and taxonomic literature (Rúgolo de Agrasar and Molina 1997; Renvoize 1998; Rúgolo de Agrasar 2012).

The presence of Agrostis species in Peru was checked against the Catalogue of the Flowering Plants and Gymnosperms of Peru (Davidse et al. 1993), additions to this (Vásquez et al. 2002; Ulloa Ulloa et al. 2004; Smith et al. 2005; Rodríguez et al. 2006; Salvador et al. 2008; Linares et al. 2010; Huamantupa et al. 2014; Gonzáles et al. 2011, 2016; Sylvester et al. 2016, 2017), and online checklists for Peru (Plants of the World Online 2020; W3TROPICOS-Peru Checklist 2020). In this treatment, glabrous means without pubescence (in the sense of slender, relatively soft hairs unless otherwise stated). Smooth indicates no prickle-hairs with broad bases and/ or hooked or pointed apices (i.e., pubescence can occur on a smooth surface, and a rough or scabrous surface can be glabrous).

Bromidium is likely a synonym of Agrostis (Tkach et al. 2020) but B. anomalum and B. tandilense, which are stated to occur in Peru (Davidse et al. 1993; Tovar 1993) and have congested inflorescences and florets lacking a palea, have not been included in the identification key. These can be easily differentiated from other Agrostis taxa by the lemma apex terminating in four scabrous setae, lemma surface often pilose, lemma with a welldeveloped geniculate awn inserted in the lower third and surpassing the glumes, calluses pilulose, caryopsis thin, with liquid endosperm (vs lemma apex entire or finely dentate with short teeth at the end of each lateral vein, lemma surface glabrous (rarely with a few hairs in Agrostis castellana L.), lemmas muticous, with a short straight awn $0.2-1 \mathrm{~mm}$ long, or with a long geniculate and twisted awn to $6+\mathrm{mm}$ long, inserted basally, medially or in the upper half of the lemma, not surpassing to greatly surpassing the glumes, calluses usually glabrous or with hairs restricted to lateral lines continuous with the basal lemma margins, caryopsis usually rounded, with hardened endosperm in Agrostis taxa from Peru).

\section{Results}

Agrostis meyenii Trin., Mém. Acad. Imp. Sci. SaintPétersbourg, Sér. 6, Sci. Math., Seconde Pt. Sci. Nat. 6(2, Bot.): 312 (-313). 1841 (Trinius 1841). Trichodium pusillum Nees \& Meyen, Mém. Acad. Imp. Sci. SaintPétersbourg, Sér. 6, Sci. Math., Seconde Pt. Sci. Nat. 6(2, Bot.): 312. 1841, nom. nud. (Trinius 1841).

Figure 1

Type. Chile. Colchagua: Cordilleras ad St. Fernando, sin. col., s.n. (holotype: LE-TRIN-1623.01 (photo SGO); isotype: BAA (BAA00001357 fragm. ex LE-TRIN [image!])).

= Agrostis canina fo. inclusa Hack., Wiss. Erb. Schwed. SüdpolarExp. 1901-1903 4 (4): 5. 1906 (Skottsberg 1906). Type: Chile. [Navarinsel, Strandwiesen] Tierra del Fuego, Isla Navarino, 4 Mar 1902, C. Skottsberg s.n. (holotype: S; isotypes: BAB (BAB00000203 [image!]; BAB00000204 [image!]), S, W (W19160035759 [image!])).

= Agrostis conferta Nees \& Meyen, Nov. Actorum Acad. Caes. Leop.-Carol. Nat. Cur. 19(Suppl. 1): 143. 1843 (Nees von Esenbeck 1843), preprint in Gramineae: 11. 1841 (Nees von Esenbeck 1841). Type: Chile. Cordillera de San Fernando, Río Tinguiririca, Feb. 1834, F.J.F. Meyen s.n. (holotype: not located; isotypes: BAA (BAA00000204 [image!]; BAA00000205 [image!]; BAA00000206 [image!])).

= Agrostis conferta Nees \& Meyen var. austropatagonica Pilg., Repert. Spec. Nov. Regni Veg. 12: 304. 1913 (Pilger 1913). Type: Argentina. [Patagonien: Santa Cruz am Belgranosee], 1908, K. Skottsberg s.n. (holotype: B; isotypes: US (US00156395! fragm. ex B).

= Agrostis falklandica Hook. f., Fl. Antarct. 2: 373. 1846 (Hooker 1846). Agrostis canina L. var. falklandica (Hook. f.) Macloskie, Rep. Princeton Univ. Exp. Patagonia, Botany 8(5): 186. 1904 (Macloskie 1904). Agrostis canina L. var. falklandica (Hook. f.) Hack. ex Skottsb., Kongl. Svenska Vetenskapsakad. Handl. 50(3): 12. 1913, hom. illeg. (Skottsberg 1913). Type: Argentina. Falkland Islands [Islas Malvinas], Antarct. Exped., 1839-1843, J.D. Hooker s.n. (holotype: K; isotypes: BAA fragm., BM (BM000938534 [image!]; BM000938533 [image!]), LE (LE00009318 [image!]), MPU (MPU014113 [image!]), P (P00740575 [image!]), US (US00156424 fragm. ex K [not seen]), W). 


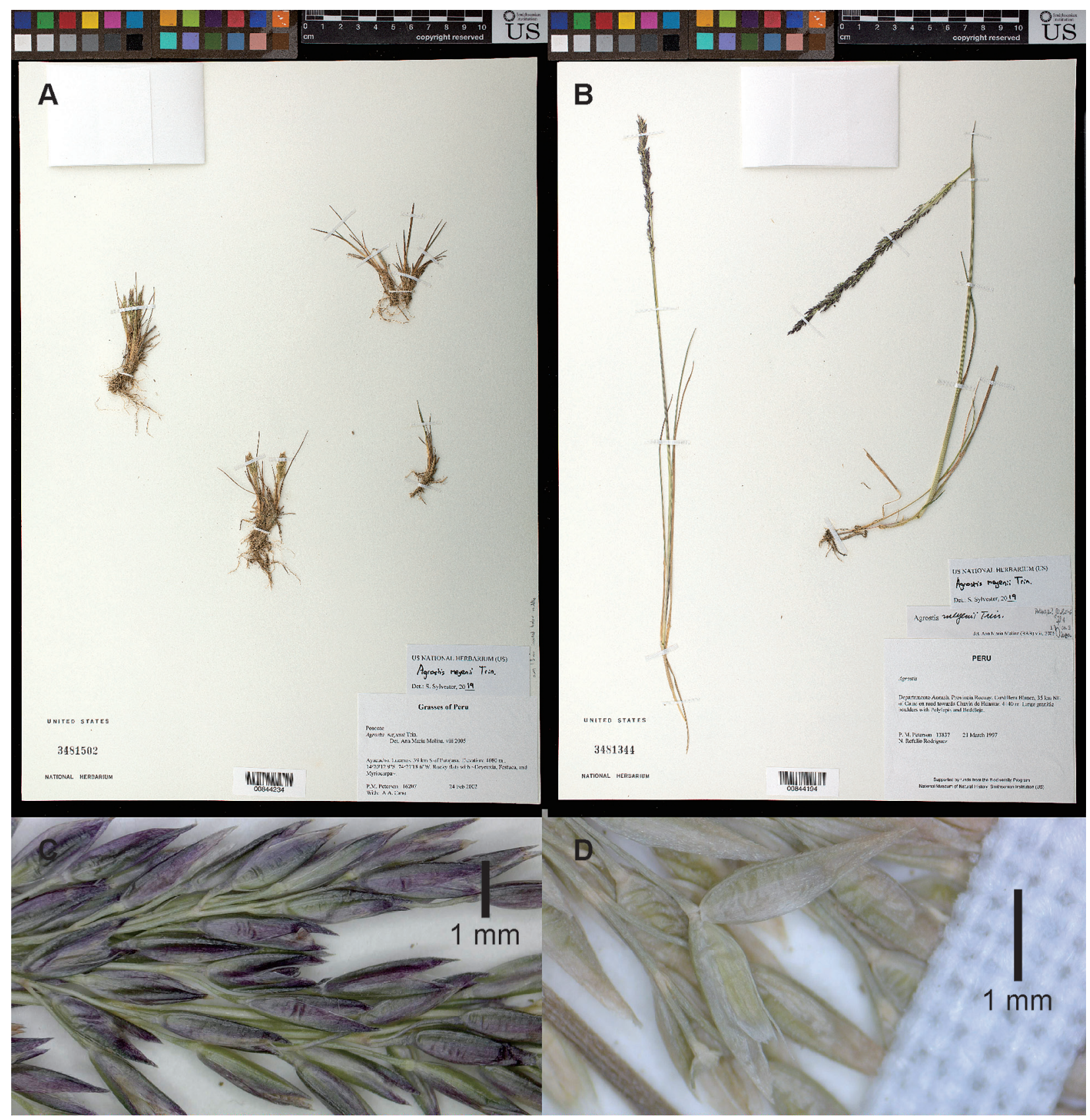

Figure 1. Agrostis meyenii. A, B. Whole plants, different examples. C. Inflorescence close-up. D. Spikelet, lateral view, with lower glume pulled back to reveal the dorsal surface of the lemma. Images A \& C: P.M. Peterson 16207 (US00844234); B \& D: P.M. Peterson 13837 (US00844194), courtesy of the US National Herbarium.

New records. PERU-Ancash • Prov. Recuay, Cordillera Blanca, $35 \mathrm{~km}$ NE of Catac on road towards Chavin de Huantar, [09 $38^{\prime} 38.69^{\prime \prime} \mathrm{S}, 077^{\circ} 12^{\prime} 6.72^{\prime \prime} \mathrm{W}$ ], $4140 \mathrm{~m}$ alt., large granitic boulders with Polylepis and Buddleja, 21 Mar. 1997, P.M. Peterson et al. 13837 (US00844194).Ayacucho - Lucanas province, $39 \mathrm{~km} \mathrm{~S}$ of Putajasa, $14^{\circ} 20^{\prime} 12.9^{\prime \prime} \mathrm{S}, 074^{\circ} 21^{\prime} 18.6^{\prime \prime} \mathrm{W}, 4080 \mathrm{~m}$ alt., rocky flats with Deyeuxia [Cinnagrostis], Festuca and Myriocarpa, 24 Feb. 2002, P.M. Peterson et al. 16207 (US00844234).Huánuco • Huamalies province, $21 \mathrm{~km} \mathrm{~N}$ of Punos on road towards Ponto, $09^{\circ} 24^{\prime} 40.1^{\prime \prime} \mathrm{S}, 076^{\circ} 56^{\prime} 02.2^{\prime \prime} \mathrm{W}, 4450$ $\mathrm{m}$ alt., open grassy slopes with Calamagrostis [Cinnagrostis], Agrostis and Poa, 23 Mar. 2004, P.M. Peterson 17920 (US00844265).
Additional material examined. ARGENTINA-Chilecito • Prov. de La Rioja, Sierra de Famatina, camino a La Mejicana, 3500 m alt., 5 Feb. 1927, L.R. Parodi 7952 (US1298751).- Mendoza • Malargue, Andes, Rio Salado headwaters, Valle de las Lenas, $36 \mathrm{~km} \mathrm{NW}$ of Las Lena son Hwy 222, $65 \mathrm{~km} \mathrm{NW}$ of Malargue, $2740 \mathrm{~m}$ alt., 5 Mar. 2006. P.M. Peterson 19194 (US00093121).Neuquen • Colorado, 1650 m alt., 19 Feb. 1940, Diem 256 (US1910171); Parque Nacional Nahuel Huapi, filo entre Mineo y Tres Marias, 25 Feb. 1953, O. Boelcke 7220 (US2929788) • Rio Negro, Bariloche, Parque Nacional Nahuel Huapi, along trail and slopes to waterfall at Cerro Tronador, $1050 \mathrm{~m}$ alt., 29 Jan. 2003, P.M. Peterson 17337 (US00786717).- Santa Cruz • Lago Buenos Aires, $77 \mathrm{~km} \mathrm{SW}$ of Los Antiguos on road towards Paso 
Roballos, 1478 m alt., 24 Jan. 2003, P.M. Peterson 17274 (US00787134) • Rio Chico, Estancia Tucu Tucu, 15 km SW of Casa Tucu Tucu, 1015 m alt., 22 Jan. 2003, P.M. Peterson 17222 (US00765622).

CHILE - Los Andes, Potrero Escondido, 3500 m alt., 22 Oct. 1910, O. Boelcke 2445 (US2919945) • Cordillera Santiago, limit nieves perpetuas, Feb. 1854, R A. Philippi 148 (US556339) - Cordillera de Talca, El Picazo, 26 Jan. 1939, sin col. 6422 (US1912077) • Cordillera de Zulia, El Alto de La Laguna, 26 Jan. 1939, Barros 6421 (US1912076).—Curico • Andes, R.A. Philippi 142 (US556333); Volcan Peteroa, 2500 m alt., Jan. 1925, E. Werdermann 583 (US1498144).--Ñuble • Baños de Chillán, 2100 m alt., 29-31 Jan. 1925, F.W. Pennell 12439 (US1343462) • Baños de Chillán, Aguas Calientes, 2200 m alt., Mar. 1927, E. Werdermann 300 (US1498182) • Termas de Chillan, Valle de Las Nieblas, $2200 \mathrm{~m}$ alt., 27 Feb. 1947, A. Pfister 7515 (US2150305).

Description. Perennial herbs, laxly to densely tufted and usually with short, delicate, incurved or vertically ascending rhizomes. Tillers extravaginal. Culms $2-15(-40) \mathrm{cm}$ tall, erect or geniculate at their base, firm, usually with 1 or 2 nodes exerted at flowering. Leaves mostly basal, glabrous; ligules (0.5-)1-3.5(-5) mm long, shorter in the tillers, truncate to obtuse; blades $2-4(-11)$ cm long, 0.1-0.25 cm wide when opened out, filiform, flat, or conduplicate, fairly lax, smooth or scabrous, apices naviculate. Inflorescence paniculate; panicles 1-10(-13) cm long, 0.3-0.7 cm wide, linear, sub-spikelike, lateral branches with spikelets almost to the base, usually smooth or lightly scaberulous, sometimes moderately scabrous; pedicels $1-4 \mathrm{~mm}$ long, usually smooth or lightly scaberulous, sometimes moderately scabrous. Spikelets (2-)2.4-3.2(-4.1) mm long; glumes lanceolate, subequal with lower glume sometimes slightly longer than upper by up to $0.2 \mathrm{~mm}$, keels usually scabrous in the distal $1 / 3$, lower glume keel sometimes scabrous in the upper $2 / 3$, upper glume sometimes completely smooth, apices acute; floret $\left(1 \frac{2-}{2}\right)^{2 / 3}-3 / 4$ the length of the glumes; calluses pilose with 2 tufts of short hairs, sometimes glabrous; lemmas 1.7-2.6 mm long, glabrous, smooth, 5-veined, apex obtuse, lightly denticulate, muticous, mucronate or exceptionally with a short awn to $1.3 \mathrm{~mm}$ long, straight, not twisted, inserted in the middle or upper $1 / 3$ of the dorsal keel, not surpassing the glumes; paleas $0.2-0.7 \mathrm{~mm}$ long, usually $<1 / 3$ the length of the lemma; anthers $0.5-0.8(-1.1) \mathrm{mm}$ long. Caryopses ca 1.1-1.6 mm long, subcylindrical, light brown; sulcus distinct; hilum punctiform; endosperm solid.

Distribution. Pampa of Argentina and Chile (Rúgolo de Agrasar 2012) and high-elevation puna grasslands of Argentina, Chile (Rúgolo de Agrasar 2012), Bolivia (Renvoize 1998; Jørgensen et al. 2014), and Peru (Fig. 2). In Peru, the species is known from the Cordillera Blanca of Ancash department and Huamalíes province of Huánuco department, as well as further south in the Lucanas province of Ayacucho department (Fig. 2).
Habitat and ecology. Throughout its range, $A$. meyenii tends to grow in humid sites among pampa and high-elevation puna grasslands, such as in damp rock crevices and swamps, or forming lawns near rivers and streams. In Peru, the species is known to grow in open or rocky humid puna grassland alongside species of Cinnagrostis Griseb., Festuca L., and Poa L., as well as growing in Polylepis Ruiz \& Pav. and Buddleja L. woodland.

Phenology. Agrostis meyenii appears to flower principally from January to March. In Peru, flowering is known from February to March, which is towards the end of the rainy season.

Similar species. Agrostis tolucensis is similar in its overall appearance, usually being tufted and with rhizomes, having similar ligules and filiform or flat leaf blades, and having a condensed spike-like panicle with spikelets of similar size. Agrostis tolucensis can usually be differentiated from $A$. meyenii by the presence of an awn inserted in the lower third of the lemma, 2-3.5 mm long, twisted and bent and exerted from the glumes (vs muticous or, if awn present, inserted in the middle or upper third of the lemma, to $1.3 \mathrm{~mm}$ long, straight or slightly flexuous in A. meyenii). Agrostis glomerata, a species described from Peru and here tentatively considered a synonym of A. tolucensis, also has muticous lemmas or with a short straight awn inserted in the upper half of the lemma, but can be differentiated from $A$. meyenii by the plants being generally taller, $20-60 \mathrm{~cm}$ tall, with flat blades to 5 $\mathrm{mm}$ wide, and condensed panicles often $>10 \mathrm{~cm}$ long that are often interrupted and with the central inflorescence axis notably wider compared to the lateral branches. The pedicels, panicle branches, and sometimes the central inflorescence axis of $A$. tolucensis and A. glomerata are also notably scabrous while those of $A$. meyenii are usually smooth or lightly scaberulous (but see below). Some specimens of A. meyenii from Argentina (Peterson 19194 (US00093121)) and Chile (Boelcke 2445 (US2919945)) were found to have many spikelets in the inflorescence slightly shorter than normal, to $2 \mathrm{~mm}$ long, which could make them be mistaken for $A$. breviculmis, but these had extravaginal branching and folded, filiform, leaf blades.

Identification key differentiating Agrostis meyenii from other species of Agrostis in Peru with condensed spike-like panicles and reduced or absent paleas $<1 / 2$ the length of the lemma (updated descriptions for taxa mentioned can be found in Sylvester et al. 2020b)

1. Lemma muticous, mucronate, or exceptionally with a short straight awn to ca $1.3 \mathrm{~mm}$ long, subapical or inserted above the middle of the lemma, weak and falling easily, not or barely exerted from the glumes 2

1'. Lemma with a dorsal awn, (1.6-)2-6 mm long, persistent, twisted and bent, exerted from the glumes 4

2. Spikelets $1.5-2.1 \mathrm{~mm}$ long $(-2.5 \mathrm{~mm}$ in Bolivia sensu Renvoize 1998); leaf blades convolute, involute, or strongly conduplicate, usually recurved, rigid, 


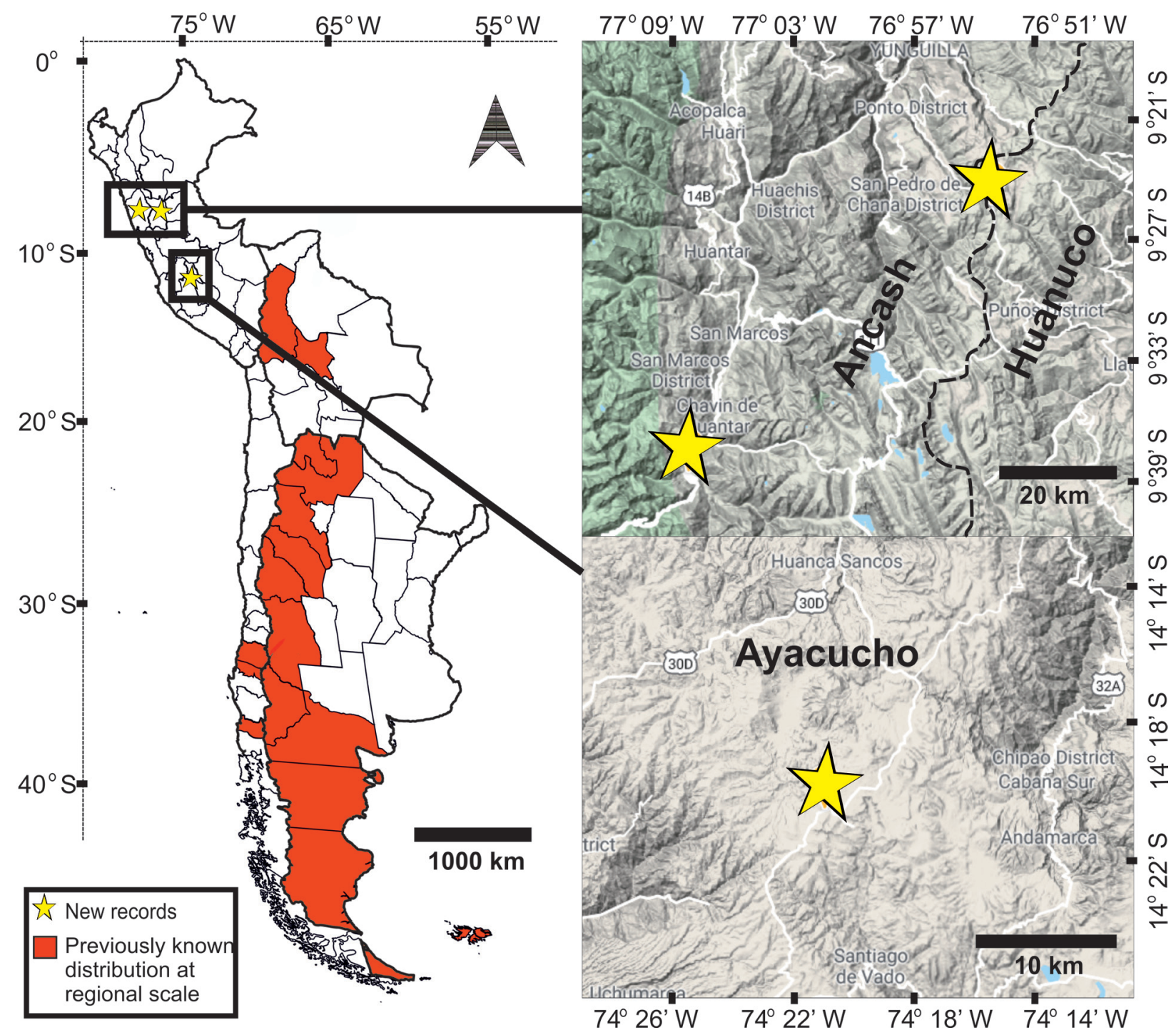

Figure 2. Distribution map of $A$. meyenii, showing the provinces of Argentina, Chile, Bolivia, and Peru, with inserts showing close-up locations of the three collections from Peru (denoted by stars). Shaded areas indicate the provinces of Bolivia, Chile, and Argentina where specimens of $A$. meyenii have been verified at the US herbarium, or which have been recorded in previous literature (Rúgolo de Agrasar and Molina 1997; Renvoize 1998; Rúgolo de Agrasar 2012). Maps taken and modified from MapChart (https://mapchart.net) and Google Earth (https://earth.google.com/).

0.5-2(-3) mm wide when opened out; tillers intravaginal, without cataphylls, not stooling and without notable lateral tending or ascending rhizomes; plants $3-12(-15) \mathrm{cm}$ tall .

A. breviculmis Hitche.

2'. Spikelets 2-4.1 mm long; leaf blades filiform, flat, conduplicate or laxly rolled, straight or flexuous, lax and soft, 1-5 mm wide when opened out (sometimes involute, recurved and/or rigid in basal leaves of $A$. tolucensis); tillers extravaginal with cataphyllous shoots present, often with notable lateral tending or ascending rhizomes or stooling; plants $2-35+\mathrm{cm}$ tall

3

3. Panicle branches, pedicels, and central inflorescence axis usually smooth or very lightly scaberulous; culms $2-15(-40) \mathrm{cm}$ tall; panicles $1-10(-13) \mathrm{cm}$ long, uninterrupted; spikelets $2.2-4.1 \mathrm{~mm}$ long; glumes subequal, keels usually scabrous in the distal $1 / 3$, lower glume keel sometimes scabrous throughout or in the upper $2 / 3$, upper glume keel sometimes completely smooth, glume surfaces smooth; lemma 1.7-2.6 mm long

A. meyenii Trin.

3'. Panicle branches, pedicels, and sometimes the central inflorescence axis moderately to densely scabrous; culms (3-)5.5-51(-80) cm tall, often $>15$ $\mathrm{cm}$ tall; panicles (1-)2-15 cm long, often $>10 \mathrm{~cm}$ long, interrupted; spikelets 2-3(-3.5) mm long; glumes equal or subequal, keels and often surfaces scabrous at least in the distal half; lemma 1.4-2 mm long A. tolucensis Kunth (= syn. Agrostis glomerata (J. Presl) Kunth)

4. Leaf blades $2-6 \mathrm{~mm}$ wide, flat or folded, sometimes somewhat involute towards their apices, subcoriaceous to coriaceous, usually scabrous throughout; flag ligules 4-7 mm long; panicle $1-1.7(-2.5) \mathrm{cm}$ 
wide, with primary lateral branches up to $7 \mathrm{~cm}$ long; spikelets (3-)3.5-4.2 mm long; floret usually ca $1 / 2$ the length of the glumes, rarely slightly longer

A. foliata Hook.f.

4'. Leaf blades 1-3(-5) mm wide, filiform, flat or folded, sometimes involute or convolute, lax to firm but not (sub-)coriaceous, scabrous in the margin and veins or smooth throughout; flag ligules $2-4(-6.2)$ mm long; panicle $0.1-1.5 \mathrm{~cm}$ wide, with primary lateral branches $0.5-1.5 \mathrm{~cm}$ long; spikelets $2-3(-$ 3.6) $\mathrm{mm}$ long; floret $1 / 2-2 / 3(-3 / 4)$ the length of the glumes A. tolucensis Kunth

\section{Discussion}

Agrostis meyenii is here presented as a new country record for Peru and is not mentioned in any of the checklists (Davidse et al. 1993; Ulloa Ulloa et al. 2004; Rodríguez et al. 2006; Plants of the World Online 2020; W3TROPICOS-Peru Checklist 2020). The species was previously known from high-elevation puna grassland and pampa of Argentina, Chile (Rúgolo de Agrasar 2012), and Bolivia (Renvoize 1998; Jørgensen et al. 2014) (Fig. 2). In Peru, A. meyenii is found in dry high-Andean puna grassland as far north as the Huamalíes province of Huánuco department, being also found close by in the Cordillera Blanca of Ancash department (Fig. 2). These collections are ca $1200 \mathrm{~km}$ to the northwest of the previously northernmost collection in Murillo, district of La Paz, Bolivia (Renvoize 1998; Jørgensen et al. 2014). The species is also found further south in Peru, in the Lucanas province of Ayacucho department, and it is likely to extend across the puna grassland biome of the central Andes, but has so far been unrecorded.

Agrostis meyenii has also been mentioned in a key for a selection of Ecuadorian and Colombian Agrostis species with contracted inflorescence at maturity with more or less appressed branches (Palacio et al. 2020), although specific reference to the species being a new country record for either Ecuador or Colombia was not stated. However, while at the US National Herbarium we have not encountered specimens of $A$. meyenii from Ecuador or Colombia, with all specimens at the US determined as A. meyenii being redetermined as A. glomerata (J. Presl) Kunth, here considered a synonym of $A$. tolucensis (see "Similar species" above). Nevertheless, the apparent affinity of $A$. meyenii for humid sites within the pampa and puna makes it plausible that it may occur in humid Jalca and páramo grasslands farther north. This notion is further supported by the large ecological amplitude exhibited by the species, with it being found from sea level in the Tierra Del Fuego (Rúgolo de Agrasar 2012) to over $4450 \mathrm{~m}$ altitude in high-Andean dry puna. The species was previously known to $4200 \mathrm{~m}$ altitude (Rúgolo de Agrasar 2012) with the Peruvian collection from Huánuco, P.M. Peterson 17920 (US00844265), marking the highest elevation recorded for the species.

Agrostis meyenii also exhibits a large amount of phenotypic variability that requires further study. While Rúgolo de Agrasar (2012) stated that the panicle branches and pedicels in $A$. meyenii are completely smooth or exceptionally scaberulous, specimens from Argentina (e.g. Boelcke 7220 (US2929788), Peterson 17222 (US00765622), 17274 (US00787134), 19194 (US00093121)), and Chile (Boelcke 2445 (US2919945), Pfister 7515 (US2150305)) bore most characteristics of A. meyenii but had moderately scabrous panicle branches and pedicels. Further study is needed to clarify the variation in this character and whether these bear more affinity to A. tolucensis. Panicle branches and pedicels of specimens studied from Peru were usually smooth or very lightly scaberulous. Peterson 13837 (US00844194) exhibits slight differences from the current circumscription of the species, being found $35-40 \mathrm{~cm}$ tall, and with culm blades to $9.5 \mathrm{~cm}$ long and panicles 8.5-13 $\mathrm{cm}$ long. The spikelets of this specimen also differed slightly, with the lower glume keels being scabrous in the upper two-thirds, while the upper glume was often smooth. Peterson 17920 (US00844265) also had particularly long leaf blades to $11 \mathrm{~cm}$ long. Specimen Peterson 16207 (US00844234) is typical of $A$. meyenii from austral South America.

\section{Acknowledgements}

This research was supported by internal funding from Nanjing Forestry University. Ingrid Lin is thanked for providing digitized specimen images. Many thanks go to Robert and Nancy Soreng and staff of the US National Herbarium, who provided assistance and support during visits by us.

\section{Authors' Contributions}

SPS designed the study, reviewed herbarium specimens, made the identifications, and wrote the manuscript; MDVPS contributed to writing the manuscript and preparing the figures.

\section{References}

Clayton WD, Renvoize SA (1986) Genera graminum. Grasses of the world. Kew Bulletin, Additional Series 13: 1-389.

Davidse G, Brako L, Tovar O (1993) Poaceae. In: Brako L, Zarucchi $\mathrm{J}$ (Eds) Catalogue of the Flowering Plants and Gymnosperms of Peru. Monographs in Systematic Botany from the Missouri Botanical Garden 45: 926-977.

Gonzáles P, La Torre MI, Cano A (2011) Deschampsia danthonioides (Poaceae-Pooideae) un nuevo registro para la flora peruana. Revista Peruana de Biología 18 (2): 185-187.

Gonzáles P, Cano A, Al-Shehbaz I, Ramírez DW, Navarro E, Trinidad H, Cueva M (2016) Doce nuevos registros de plantas vasculares para los Andes de Perú. Arnaldoa 23 (1): 159-170.

Hooker JD (1846) Flora Antarctica. Part II., botany of Fuegia, the Falklands, Kerguelen's Land, etc. In: Hooker JD (Ed.) The botany of the Antarctic Voyage of H.M. Discovery ships Erebus and Terror in the years 1839-1843 .... Reeve Brothers, London, 209-574. https://doi.org/10.5962/bhl.title.16029 
Huamantupa I, Vásquez R, Foster R, Cuba M, Calatayud G (2014) Adiciones de angiospermas a la Flora del Perú procedentes de los bosques Andino Amazónicos del sur peruano. Revista Peruana de Biología 21 (2): 163-170. https://doi.org/10.15381/rpb.v21i2.9819

Jørgensen PM, Nee MH, Beck SG (2014). Catálogo de las plantas vasculares de Bolivia. Monographs in systematic botany from the Missouri Botanical Garden 127 (1-2): i-viii, 1-1744. Missouri Botanical Garden Press, St. Louis.

Linares E, Campos J, Nauray W, Vicente J, Galán De Mera A (2010) Nuevas adiciones a la flora del Perú, V. Arnaldoa 17 (1): 99-106.

Macloskie G (1904) Part V. Flora Patagonica. Flowering plants. Reports of the Princeton University Expeditions to Patagonia, 18961899 ... Volume viii, 1 [2], Botany 8 (1,5,1): 139-466.

Nees von Esenbeck CGD (1841) Graminea. Vratislaviae, pp. 76

Nees von Esenbeck CGD (1843) Gramineae. In: Meyen FJF (Ed.) Beiträge zur Botanik. Novorum Actorum Academiae Caesareae Leopoldinae-Carolinae Naturae Curiosorum, Verhandlungen der Kaiserlichen Leopoldinisch-Carolinischen Akademie der Naturforscher 19 (Suppl. 1), Eduard Weber Buchhandlung, Breslau [Wrocław] \& Bonn, 133-208.

Palacio PC, Molina AM, Rúgolo de Agrasar ZE, Vega AS (2020) A new species of Agrostis (Poaceae, Pooideae, Poeae, Agrostidinae) from the Andean Páramos of Colombia and Ecuador. Novon 28 (3): 171-178. https://doi.org/10.3417/2020544

Pilger RKF (1913) LII. Gramineae novae, a cl. K. Skottsberg in Patagonia australi et in Fuegia collectae. Repertorium Specierum Novarum Regni Vegetabilis 12: 304-308.

Plants of the World Online (2020) http://www.plantsoftheworldonline. org. Accessed on: 2020-8-27.

Renvoize SA (1998) Gramíneas de Bolivia. Continental Printing, Belgium, $676 \mathrm{pp}$.

Rodríguez EF, Vásquez R, Rojas R, Calatayud G, León B, Campos J (2006) Nuevas adiciones de angiospermas a la flora del Perú. Revista Peruana de Biología 13 (1): 129-138.

Rúgolo de Agrasar ZE, Molina AM (1997) Las especies del genero Agrostis L. (Gramineae: Agrostideae) de Chile. Gayana Botanica 54 (2): 91-156.

Rúgolo de Agrasar ZE (2012) Agrostis L. In: Zuloaga FO, Rúgolo de Agrasar ZE, Antón AM (Eds) Flora Argentina. Poaceae: Pooideae. Volumen 3, tomo 2. IBODA-IMBIV, CONICET, Buenos Aires, Argentina, 102-125.

Salvador F, Ángeles M, Ríos S (2008) Tres nuevos registros del genero Carex (Cyperaceae) para el Perú y adiciones a la flora andina del departamento de Huánuco. Revista Peruana de Biología 15 (2): 83-92.

Skottsberg C (1906) Zur Flora des Feuerlandes. Wissenschaftliche Ergebnisse der Schwedischen Südpolar-Expedition 1901-1903, Band 4 Botanik, Abteilung 4: 1-42.

Skottsberg C (1913) Botanische ergebnisse der Schedischen expedition nach Patagonien und dem Feuerlande 1907-1909, III. A botanical survey of the Falkland Islands. Kongliga Svenska Vetenskaps Academiens Handlingar (Ny Följd) 50 (3): 1-129.

Smith AR, León B, Tuomisto H, Van der Werff H, Moran RC, Lehnert M, Kessler M (2005) New records of pteridophytes for the Flora of Peru. Sida 21: 2321-2341.

Soreng RJ, Peterson PM (2003) Agrostis. In: Soreng RJ, Peterson PM, Davidse G, Judziewicz EJ, Zuloaga FO, Filguieras TS, Morrone
O (Eds) Catalogue of New World grasses (Poaceae): IV. Subfamily Pooideae. Contributions from the United States National Herbarium 48: 42-89.

Soreng RJ, Davidse G, Peterson PM, Zuloaga FO, Judziewicz EJ, Filgueiras TS, Morrone O (2003 and onwards). Catalogue of New World grasses. http://www.tropicos.org/project/Cnwg. Accessed on: 2019-11-18

Soreng RJ, Peterson PM, Romaschenko K, Davidse G, Teisher JK, Clark LG, Barberá P, Gillespie LJ, Zuloaga FO (2017) A worldwide phylogenetic classification of the Poaceae (Gramineae) II: an update and a comparison of two 2015 classifications. Journal of Systematics and Evolution 55: 259-290. https://doi.org/10.1111/ jse. 12262

Sylvester SP, Soreng RJ, Peterson PM, Sylvester MDPV (2016) An updated checklist and key to the open-panicled species of Poa (Poaceae) in Peru including three new species, Poa ramoniana, Poa tayacajaensis, and Poa urubambensis. PhytoKeys 65: 57-90. https://doi.org/10.3897/phytokeys.65.7024

Sylvester SP, Sylvester MDPV, Kessler M (2017) Four new and five overlooked records of vascular plants from the southern Peruvian Andes. Arnaldoa 24 (1): 229-238. http://doi.org/10.22497/ arnaldoa.241.24108

Sylvester SP, Peterson PM, Romaschenko K, Bravo-Pedraza WJ, Cuta-Alarcon LE, Soreng RJ (2020a) New combinations and updated descriptions in Podagrostis (Agrostidinae: Poaceae) from the Neotropics and Mexico. PhytoKeys 148: 21-50. https://doi. org/10.3897/phytokeys.148.50042

Sylvester SP, Cuta-Alarcon LE, Bravo-Pedraza WJ, Soreng RJ (2020b) Agrostis and Podagrostis (Agrostidinae: Poaceae) from páramos of Boyacá, Colombia: synoptic taxonomy including a key to Colombian species. PhytoKeys 151: 107-160. https://doi. org/10.3897/phytokeys.151.50538

Thiers B (2020) [continuously updated] Index Herbariorum: a global directory of public herbaria and associated staff. New York Botanical Garden's Virtual Herbarium. http://sweetgum.nybg.org/ ih/. Accessed on: 2020-08-18

Tkach N, Schneider J, Döring E, Wölk A, Hochbach A, Nissen J, Winterfeld G, Meyer S, Gabriel J, Hoffmann MH, Röser M (2020) Phylogenetic lineages and the role of hybridization as driving force of evolution in grass supertribe Poodae. Taxon 69 (2): 234 277. https://doi.org/10.1002/tax.12204

Tovar O (1993) Las Gramíneas (Poaceae) del Perú. Ruizia 13: 1-480.

Trinius CB (1841) Gramina Agrostidea, II, Callus Rotundus (Agrostea). Mémoires de l'Académie Impériale des Sciences de Saint-Pétersbourg, Sixième Série, Sciences Mathématiques, Physiques et Naturelles, Seconde Partie: Sciences Naturelles 6 (2, Botanie): 247-390.

Ulloa Ulloa C, Zarucchi J, León B (2004) Diez años de adiciones a la flora del Perú: 1993-2003. Arnaldoa, Ed. Especial: 7-242. https:// doi.org/10.5962/bhl.title.63538

Vásquez R, Rojas R, Rodríguez E (2002) Adiciones a la Flora Peruana: especies nuevas, nuevos registros y estados taxonómicos de las Angiospermas para el Perú. Arnaldoa 9 (2): 43-110.

Watson L, Dallwitz MJ (1992) The grass genera of the world. CAB International, Wallingford, $1024 \mathrm{pp}$.

W3TROPICOS-Peru Checklist (2020) Missouri Botanical Garden. http://legacy.tropicos.org/Project/PEC. Accessed on: 2020-1-12. 